\section{Facies}

January 2010, Volume 56, Number 1, Pages 13-25

http://dx.doi.org/10.1007/s10347-009-0196-2

(c) 2010 Springer. Part of Springer Science+Business

Media

The original publication is available at http://www.springerlink.com
Archimer, archive institutionnelle de l'Ifremer http://www.ifremer.fr/docelec/

\title{
A latitudinal gradient of seasonal temperature variation recorded in oyster shells from the coastal waters of France and The Netherlands
}

\author{
Franck Lartaud ${ }^{1,4,{ }^{*}}$, Laurent Emmanuel ${ }^{1}$, Marc de Rafelis ${ }^{1}$, Michel Ropert ${ }^{2}$, Nathalie Labourdette ${ }^{1}$, \\ Christopher A. Richardson ${ }^{3}$ and Maurice Renard ${ }^{1}$
}

${ }^{1}$ UPMC Paris 06, UMR 7193, ISTeP-Lab. Biominéralisations et Environnements sédimentaires, Case postale 116, 4 place Jussieu, 75252 Paris Cedex 05, France

${ }^{2}$ Laboratoire Environnement Ressource de Normandie (LERN), IFREMER, BP 32, Avenue du Général de Gaulle, 14520 Port-en-Bessin, France

${ }^{3}$ School of Ocean Sciences, College of Natural Sciences, Bangor University, Menai Bridge, Anglesey, LL59 5AB, UK

${ }^{4}$ Present address: IUEM-UBO, UMR CNRS 6539, Lab. Sciences de l'Environnement Marin (LEMAR),

Technopôle Brest-Iroise, Place N. Copernic, 29280 Plouzané, France

*: Corresponding author : Lartaud F., email address : franck.lartaud@univ-brest.fr

\begin{abstract}
:
Cathodoluminescence (CL) microscopy of the foliated calcite shell hinge sections of live-collected oyster Crassostrea gigas collected at seven locations along a latitudinal gradient from the Netherlands in the North Sea to the Atlantic coast of France, revealed variations in luminescence that were attributable to seasonal variations in calcification of the hinge. Photomicrographs of hinge sections and luminescence profiles were analyzed to define a micro-sampling strategy that was adopted to drill the hinge samples to determine their isotopic composition. Reconstructed seasonal seawater temperatures determined from the stable oxygen isotope $\left(\delta^{18} \mathrm{O}\right)$ composition along growth profiles from 32 oyster shell hinges showed distinct seasonal isotopic cycles that were compared with in situ measured seawater temperatures and salinities at each location. Comparison of the amplitude of the $\left(\delta^{18} \mathrm{O}\right)$ signal and the annual maximum and minimum seawater temperatures demonstrated that $C$. gigas shells from several locations provided a reliable record of seasonal seawater temperature variation. The exception to this was oysters from the Netherlands and northern France where winter growth rates at low temperatures were slow so that insufficient shell was deposited to allow adequate spatial resolution of sampling and this resulted in time-averaging of the reconstructed seawater temperatures and an overestimation of winter seawater temperature. A potential variability in $\delta^{18} \mathrm{O}_{w}-$ salinity relationship at low salinities could also explain the high difference between measured and predicted seawater temperatures in Dutch areas. The finding that latitudinal differences in oyster hinge growth rates and/or changes in the $\delta^{18} \mathrm{O}_{w}$-salinity relationship can result in bias of the seawater temperature deduced from the stable isotopic composition of the hinge should be taken into account when reconstructing latitudinal gradients in seawater temperature.
\end{abstract}

Keywords: Mollusk shells - Crassostrea gigas - Cathodoluminescence - Stable isotopes Palaeotemperatures - Seasonality 


\section{Introduction}

The stable isotopic $\left(\delta^{18} \mathrm{O}\right)$ composition of calcite in mollusc shells has been shown to be a reliable proxy for changes in seawater temperature and salinity (e.g. Epstein et al. 1953; Carter 1980; Schein et al. 1991; Surge et al. 2001). The geochemical composition of bivalve shells can provide information on the temporal changes of a range of environmental factors over both long- (multi-annual), mid- (seasonal) and short-term (lunar and tidal) time scales (e.g. Arthur et al. 1983; Richardson 2001; Schöne 2003). Although many authors have utilised bivalve shells to reconstruct the seasonal evolution of environmental conditions at specific locations (e.g. Killingley and Berger 1979; Kennedy et al. 2001; Mueller-Lupp et al. 2003; Dettman et al. 2004; Schöne et al. 2004), few studies, however, have investigated the isotopic composition of mollusc shells along latitudinal gradients (see Jones and Quitmyer 1996; Khim et al. 2000; Elliot et al. 2003; Schöne et al. 2003). Harrington (1989) has underlined the importance of understanding the effects of geographical position on environmental records in shells of the same species.

Oysters of the genus Crassostrea and Ostrea are well suited to stable isotopic studies owing to their ability to deposit their shell in isotopic equilibrium with seawater over a wide range of ecological settings, from coastal shelf seas to intertidal areas (Hong et al. 1995; Kirby et al. 1998; Surge et al. 2001). Moreover, oysters have a wide latitudinal and temporal distribution in geological time (Stenzel 1971). The understanding and interpretation of the incorporation of shell oxygen isotopes requires a temporal frame within the shell from which to develop a model of shell growth. Many mollusc shells contain periodically deposited internal growth lines, checks and bands (Richardson 2001; Higuera-Ruiz et al. 2009; Wisshak et al. 2009) or external morphological growth rings and striae that can be used as chronological markers in or on the shell (e.g. Lawrence 1988; Kirby et al. 1998). However, these kinds of periodic structures are not always readily apparent or suitably preserved in all oyster species (Rhoads and Lutz 1980; Lartaud et al. 2006), and even when growth checks are present they do not always provide reliable annual records of shell growth (Surge et al. 2001).

Cathodoluminescence (CL) can provide an alternative approach for identifying growth increments within biogenic carbonate shells that are not normally visible using conventional microscopy (Barbin et al. 1991; Barbin 2000). The bombardment of biogenic carbonates with a cathode ray leads to the emission of photons by manganese ions $\left(\mathrm{Mn}^{2+}\right)$ resulting in luminescence of the ions within the shell matrix. Experimentally marking oyster shells with $\mathrm{MnCl}_{2}$ produces an internal fluorescent line that can be detected in the shell under $\mathrm{CL}$ 
(Langlet et al. 2006; Lartaud 2007). These induced fluorescent lines have been used to mark the beginning of growth in oyster shells to which all subsequent growth can be related and have been used to investigate the formation of microgrowth increments in the shell. Using the technique seasonal, spring-neap lunar and tidal patterns of growth increments have been observed in the hinge region of oyster Crassostrea gigas, shells from lagoonal environments e.g. Thau pond, France (Langlet 2002; Langlet et al. 2006) and from European Atlantic coasts (Lartaud 2007). These tidally deposited microgrowth lines have chronological significance and are-visible in $\mathrm{CL}$ and can be used to define the sample positions for drilling the calcite samples for isotope analysis.

In this paper we investigate the seasonal relationship between the stable isotope composition of oyster shell calcite and environmental conditions (seawater temperature and salinity). We use seasonal variations in luminescence in hinge sections and the tidal microgrowth increments to define the patterns of seasonal growth in the hinge region. We investigate whether the isotopic composition of the shells can be used reliably to reconstruct seasonal seawater temperatures in oysters collected at two locations in the Netherlands in the North Sea and at five locations along the French coastline.

\section{Material and methods}

the north and north west Atlantic coastlines of France between latitude $53^{\circ} \mathrm{N}$, north of the Netherlands, to $44^{\circ} \mathrm{N}$ in Arcachon basin, France (Fig. 1). Sampling of oysters occurred in two wave-sheltered Dutch sites (sites 1 and 2, Texel and Yerseke respectively) and at five coastal commercial French oyster farms (site 3, Baie des Veys (exposed) in the English Channel; site 4, Fort-Espagnol (wave-sheltered) in Brittany; site 5, Marennes-Oléron in Charente-Maritime (wave-sheltered); sites 6 and 7 Tès (wave-sheltered) and Ferret (exposed) respectively in Arcachon Basin). All of the locations are influenced by semi-diurnal tidal regimes. Daily measurements of seawater temperature and salinity at the oyster farms were provided by IFREMER (Institut Français de Recherche et d'Exploitation de la Mer) and in the Netherlands the Texel data were provided by the NIOZ (Royal Netherlands Institute for Sea Reseach, H. Van Aken, unpublished data, 2004). Only mean monthly records were available for Yerseke from the Dutch Center of Hydrology and Meteorology database (http://hmcz.nl).

In France, oyster Crassostrea gigas (Thunberg, 1793) spat, (size $20 \mathrm{~mm}$ umbo-margin axis), were sourced from the IFREMER hatchery at La Tremblade, (Charente-Maritime) and transplanted until they were six months old into nursery tanks at Bouin (Vendée, Fig. 1). In these tanks the spat were fed daily for two weeks 
with a diet of micro-algae (Skeletonema costatum) that had been cultured in seawater enriched with manganese

106 (see Pirastru 1994; Hussenot and Buchet 1998) in order to internally mark their shells with a manganese spike

107 that could be later identified with CL. These spats were then transplanted onto oyster tables at two locations

108 (sites 3 and 4), Baie des Veys and Fort-Espagnol respectively. Oyster spat destined for transplantation at

109 Marennes-Oléron (site 5) were transferred from nursery tanks at Bouin (Fig. 1) and held in an oyster pond for

$110 \sim 6$ months (September 2001 to March 2002) before relaying onto oyster tables. Approximately 24-30 months

111 after the oysters were relayed onto the oyster tables in February 2001 (site 5) and in March 2002 (sites 3 and 4) a

112 sample of $\sim 20$ oysters were collected (see table 1). Oysters that had settled naturally during July 2001 in

113 Arcachon basin were transplanted onto oyster tables in the Morbihan (France) during 12 months before located

114 at sites 6 and 7, Tès and Ferret respectively and ongrown until they were collected in March 2004. The

115 Netherlands oysters (40-50 mm and of unknown settlement date) were collected from natural wild recruited

116 populations in October 2003. The growing conditions experienced by the oysters from the different regions are

117 shown in Table 1.

118 Immediately upon collection the oysters were carefully opened in the field by cutting through the adductor

119 muscle avoiding any damage to the hinge area and the flesh scrapped and removed from the inner surface of the

120 shell valves to avoid any post-mortem carbonate dissolution following the oysters' aerial emersion. Upon return

121 to the laboratory the shells were placed in a $6 \%$ solution of Hydrogen peroxide $\left(\mathrm{H}_{2} \mathrm{O}_{2}\right)$ for 6 hours to remove

122 any epibiota from the outer shell surfaces, washed in $0.15 \mathrm{~N}$ Nitric acid for 20 minutes to dissolve any carbonate

123 based superficial contamination and rinsed in demineralised water ( 5 mins.) The dry left shell valve of each

124 oyster was cut along the maximum growth axis through the middle of the hinge region to the ventral shell 125 margin (see Fig. 2).

126 The position of the annual growth lines and finer tidally deposited growth increments were determined

127 from shell cross sections viewed under cathodoluminescence (see Langlet 2002; Langlet et al. 2006; Lartaud

1282006 for methodologies). Cold cathode (Cathodyne-OPEA, $15-20 \mathrm{kV}$ and 200 to $300 \mu \mathrm{A} . \mathrm{mm}^{-2}$ under a pressure $^{-2}$

129 of 0.05 Torr) observations were made on the foliated calcite of the hinge section (see Fig. 3), because this area

130 contains an ontogenetic record of both the oysters' hinge growth and the environmental conditions experienced

131 throughout their life (Stenzel 1963; Carriker and Palmer 1979; Richardson et al. 1993; Kirby et al. 1998).

132 Following the methodologies of Langlet et al. (2006) and Lartaud et al. (2006), CL-intensity variations across

133 the hinge sections were analysed using the software Image J-1.33 (http://rsbweb.nih.gov/ij/) to determine 
134 microscopic changes in CL that would reveal the patterns of incremental growth lines in the hinges of the oyster 135 shells. In this way, given the known date of death of the oyster shells and date of induction of a luminescent line 136 following laboratory exposure to manganese enriched algae, it was possible to assign a date to each of the tidal 137 increments and thus provide a chronology to the hinge growth which assisted in determining a 138 sclerochronological profile along the hinge that could be sampled for stable isotopes (see Fig. 3).

139 Samples of shell calcium carbonate for $\delta^{18} \mathrm{O}$ and $\delta^{13} \mathrm{C}$ analysis were drilled out, to a depth of $\sim 0.1 \mathrm{~mm}$, 140 from along each identified growth line in the foliated layers of the hinge region using a $0.5 \mathrm{~mm}$ diameter drill.

141 The number of drilled samples varied depending on the distance between each annual growth line. Collected 142 powders were acidified in $100 \% \mathrm{H}_{3} \mathrm{PO}_{4}$ at $50^{\circ} \mathrm{C}$ under vacuum. The $\mathrm{CO}_{2}$ produced was collected and analysed 143 using a mass spectrometer (VG Micromass 602). Isotopic data are reported in conventional delta ( $\delta$ ) notation 144 relative to the Vienna Pee Dee Belemnite (VPDB). The standard used for the analyses was an internal standard 145 calibrated on the NBS-19. Standard deviation for $\delta^{18} \mathrm{O}$ and $\delta^{13} \mathrm{C}$ is $\pm 0.10 \%$.

146 Since salinity and $\delta^{18} \mathrm{O}_{\text {water }}(\%$ VSMOW) are known to be related, the measured seasonal average salinity 147 at each location was converted into $\delta^{18} \mathrm{O}_{\text {water }}$ values using salinity $/ \delta^{18} \mathrm{O}_{\text {water }}$ relationships. Oxygen isotope data 148 from different coastal waters are affected by different estuarine river influx and evaporation rates in different 149 geographical areas (Schmidt 1999), therefore published $\delta^{18} \mathrm{O}_{\text {water }}$-salinity equations specific to each oyster 150 location were applied to estimate the $\delta^{18} \mathrm{O}_{\text {water }}$ values from the salinity data. For Texel (site 1), the equation of 151 Harwood et al. (2008) $\left(\delta^{18} \mathrm{O}_{\text {water }}=0.274 \mathrm{xSalinity}-9.3 ; \mathrm{R}^{2}=0.89 ; \mathrm{N}=247\right)$, for Yerseke (site 2), the equation of 152 Gillikin (2005) $\left(\delta^{18} \mathrm{O}_{\text {water }}=0.20 \mathrm{xSalinity}-6.31 ; \mathrm{R}^{2}=0.97 ; \mathrm{N}=63\right)$ and for the French locations (site 3 to 7 ) the 153 equation of Lartaud (2007) established at different locations from the English Channel and the Atlantic coasts of 154 France $\left(\delta^{18} \mathrm{O}_{\text {water }}=0.22 x\right.$ Salinity $\left.-7.30 ; \mathrm{R}^{2}=0.73 ; \mathrm{N}=62\right)$ were used to convert the salinity data to $\delta^{18} \mathrm{O}_{\text {water }}$. Shell $155 \delta^{18} \mathrm{O}$ data $(\% \mathrm{VPDB})$ were then converted to seawater temperatures using the paleotemperature equation of 156 Anderson and Arthur (1983) derived from molluscan shells, where 157 Temperature seawater $\left.^{\circ} \mathrm{C}\right)=16-4.14\left(\delta^{18} \mathrm{O}_{\text {shell }}-\delta^{18} \mathrm{O}_{\text {water }}\right)+0.13\left(\delta^{18} \mathrm{O}_{\text {shell }}-\delta^{18} \mathrm{O}_{\text {water }}\right)^{2}$. Because data set was small at 158 some locations, comparison between predicted and measured ST have been tested using the non-parametric 159 Mann-Whitney U test.

160

\section{Results}


The measured seasonal seawater temperature and salinities at each of the seven locations are shown in

164 Figure 4 and demonstrate a latitudinal gradient across the Dutch and French Locations. The maximum mean annual seawater temperatures were $11.5^{\circ} \mathrm{C}$ and $12.8^{\circ} \mathrm{C}$ for the Netherlands and northern French locations respectively, whereas the mean seawater temperatures in south west France were slightly higher at around $13.5^{\circ} \mathrm{C}$. The northern French location, Fort-Espagnol (Brittany), showed a greater mean annual seawater temperature of $16.8^{\circ} \mathrm{C}$. The amplitude of the seasonal changes was variable from one site to another. The Dutch sites from the shallow North Sea showed the greatest annual seawater temperature fluctuations; a difference of $24^{\circ} \mathrm{C}$ was recorded at Yerseke and $23^{\circ} \mathrm{C}$ at Texel. By contrast, oysters from Baie des Veys and Marenne-Oléron showed a reduced seasonal contrast (between $15^{\circ} \mathrm{C}$ and $14^{\circ} \mathrm{C}$ ). Mean salinities were lower at the Dutch locations (27.8 PSU at Texel and 30.7 PSU at Yerseke) than at the French locations where the annual-mean salinities were 173 close to or $>32$ PSU The protected environments at Tes (in Arcachon Basin) and Texel sites (in the North Sea) revealed the greater salinity ranges $\sim 15$ PSU whilst the more wave-exposed areas (Baie des Veys and Yerseke) had the lowest variations ( $<5$ PSU). Profiles of $\delta^{18} \mathrm{O}_{\text {shell }}$ and $\delta^{13} \mathrm{C}_{\text {shell }}$ of the hinge regions are plotted as function of shell height in Figure 5. $177 \delta^{18} \mathrm{O}_{\text {shell }}$ of all of the oysters sampled from the seven locations show seasonal variations (Fig. 5 and Table 2).

178 Except for the shells from the Netherlands locations which have highly negative mean values $(-1.4 \pm 0.6 \%$ for 179 Texel and $-1.3 \pm 0.3 \%$ for Yerseke), the mean $\delta^{18} \mathrm{O}_{\text {shell }}$ along the latitudinal gradient ranged between $180-0.2 \pm 0.4 \%$ (Tes, Arcachon Basin) to $0.3 \pm 0.2 \%$ (Marennes-Oléron). Isotopic values for the shell part 181 corresponding to the nursery at Bouin (France) are slightly lower $\left(-0.4 \pm 0.2 \%\right.$ ). The maximum annual $\delta^{18} \mathrm{O}_{\text {shell }}$ 182 variations were observed at Baie des Veys and Tes (close to $2.0 \%$ ) whereas minimum variations were observed 183 in hinges of oysters from Yerseke $(0.5 \%)$ and Marennes-Oléron $(0.9 \%)$.

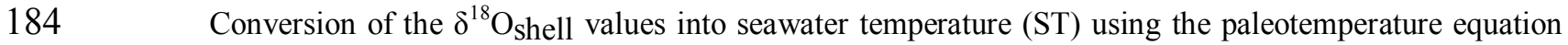
185 produced a range of maximum and minimum ST's (Fig. 6 and Fig. 7). For example the hinge region of the shells 186 recorded ST maxima of $23.3^{\circ} \mathrm{C}$ at location 4 (Fort-Espagnol), 22.7 at location 2 (Yerseke) and $22.5^{\circ} \mathrm{C}$ at location 1871 (Texel, see table 2), whilst minimum ST of $5.9^{\circ} \mathrm{C}$ were recorded in shells from location 5 (Marennes-Oléron, 188 France). The largest annual range in ST was observed at Tès (location 6) and at Fort-Espagnol (location 4), with 189 a range of $13.1^{\circ} \mathrm{C}$ and $11.2^{\circ} \mathrm{C}$ respectively. The lowest seasonal range $\left(3.4^{\circ} \mathrm{C}\right)$ appeared in hinges of shells from 190 location 2 at Yerseke, in the Netherlands. The lowest mean annual ST was recorded in oysters from location 5 at 191 Marennes-Oléron $\left(12.3 \pm 2.2^{\circ} \mathrm{C}\right)$ whereas shells from location 2 (Yerseke, the Netherlands) and to a lesser extent 
192 from location 4 (Fort-Espagnol, France) showed the highest mean annual ST's $\left(20.5 \pm 1.6^{\circ} \mathrm{C}\right.$ and $16.4 \pm 1.0^{\circ} \mathrm{C}$

193 respectively, see Figure 7). Only small differences were apparent in the average annual reconstructed ST

194 between oysters of the same age from the same site (Table 2). The average reconstructed summer ST from the

195 oyster hinges was not significantly different from the measured ST (Mann-Whitney test, $\mathrm{p}<0.05$; Table 3) at all

196 locations, except Yerseke ( $\mathrm{z}=-2.698, \mathrm{p}=0.003$; Table 3). By contrast the average predicted winter ST's were

197 significantly lower than the measured winter ST's in oysters from the northern locations (Texel and Yerseke in

198 the Netherlands, Baie-des-Veys in France; Table 3) and in Marennes-Oléron ( $\mathrm{z}=-2.252, \mathrm{p}=0.012)$, but not

199 significantly different at the other French locations.

$200 \quad \delta^{13} \mathrm{C}_{\text {shell }}$ do not show clear seasonal variations. Isotopic values are higher during summer in Yerseke,

201 Baie des Veys, Fort-espagnol, Marennes-Oléron and Ferret, but not in Texel and Tès (Figure 5). The average

$202 \delta^{13} \mathrm{C}_{\text {Shell }}$ values range from $-1.9 \pm 0.2 \%$ (Yerseke) to $-0.2 \pm 0.2 \%$ (Ferret, Arcachon Basin). The Dutch locations

203 and shell part corresponding to nursery at Bouin records the lower values (always lower than $-1.4 \pm 0.2 \%$ )

204 whereas French sites have mean values up to $-0.7 \pm 0.1 \%$ (Table 2 ).

205

Discussion

The accuracy of the seawater temperature (ST) estimated from the $\delta^{18} \mathrm{O}_{\text {shell }}$ together with low intraspecific variability in the ST estimated from different oyster shell hinges demonstrates that considerable confidence can be attached to the ST's from the foliated calcite shell of Crassostrea gigas. Mean annual ST's

211 determined from the $\delta^{18} \mathrm{O}_{\text {shell }}$ compared favourably with in situ measurements of the mean annual ST range 212 across their studied latitudinal range. These results are in accordance with the works of Hong et al. (1995), Kirby 213 et al. (1998) and Surge et al. (2001) who demonstrated that oxygen isotopes are incorporated into oyster shells 214 close to isotopic equilibrium with seawater and without intra-specific fractionation. The observed almost exact 215 correspondence between the maximum estimated ST from the $\delta^{18} \mathrm{O}_{\text {shell }}$ in oyster hinges, except those from 216 location 2 at Yerseke, and the maximum recorded measured summer in situ ST's strongly supports this.

217 By contrast the oyster shell hinges showed considerable variation in their ability to record the minimum 218 winter ST's. Shells from all the French locations except station 6 (Tès), where there was exact correspondence 219 between the estimated ST's from the $\delta^{18} \mathrm{O}_{\text {shell }}$ and the in situ ST, recorded temperatures between 1 and $3^{\circ} \mathrm{C}$ 220 higher than the mean winter measured ST (Table 3). This disparity between the shell recorded winter minimum 
221 ST and the measured ST was even greater in oyster hinges from the shallow boreal water locations in the North 222 Sea where a difference $>5^{\circ} \mathrm{C}$ was apparent.

223 The lack of calcification in the American oyster Crassostrea virginica due to a skeletal growth break 224 during the coldest periods of the year (Loosanoff and Nomejko 1949; Galstoff 1964) may offer an explanation 225 for the difference between the predicted and observed ST's in this study. Quayle (1988) and Kirby et al. (1998), 226 for example, noted that shell deposition ceased in the shells of C. gigas from British Columbia, Canada, at 227 temperatures $<10^{\circ} \mathrm{C}$ and Langlet et al. (2006) found that daily shell growth rates in oysters decreased from 30 to $22810 \mu \mathrm{m}$ between the summer and winter. Cessation in shell growth will introduce a gap in the isotopic values 229 during the winter period. A reduction in calcification rate during winter in C.gigas was observed to cause a 230 decrease in temporal resolution of the analytical sampling (Hong et al. 1995) and this probably resulted in time 231 averaging of the $\delta^{18} \mathrm{O}_{\text {shell }}$ during the winter period. The resultant effect would be a mixing of winter and mid232 season $\delta^{18} \mathrm{O}_{\text {shell }}$ in the drilled samples and would produce lower isotopic values (i.e. higher estimated winter 233 ST's) during the winter period than might have been expected (Harrington 1989; Goodwin et al. 2003). 234 However, our results suggest that seawater temperatures below $10^{\circ} \mathrm{C}$ can be clearly recorded in the shell 235 carbonate (i.e. ST records $<8^{\circ} \mathrm{C}$ in Marennes-Oléron shells).

None of the Dutch oysters from Texel and Yerseke showed a good correlation between the $\delta^{18} \mathrm{O}_{\text {shell }}$ 237 predicted values and the observed ST's during the winter, when ST's were minimal, and during the summer the 238 oyster shells from Yerseke over-estimated the measured in situ ST's. Oysters from the more southern French 239 locations continued to grow, albeit slowly during the winter and this made it easier to drill discrete carbonate 240 samples and reconstruct the colder winter ST's in these regions than in the Northern Dutch sites. Dutch locations 241 where the growth experiments were conducted were exposed to salinity fluctuations as a result of anthropogenic 242 pressure causing large releases of freshwater during polder flooding, which cannot be recorded with monthly 243 measurements in Yerseke (see Material and methods). The decrease in salinity and high input of terrestrial 244 organic matter bring about both $\delta^{18} \mathrm{O}_{\text {shell }}$ and $\delta^{13} \mathrm{C}_{\text {shell }}$ reduction (Tivollier and Létolle 1968; Surge et al. 2001; 245 Gillikin et al. 2006). Isotopic measurements of seawater collected in the Scheldt estuary close to Yerseke by 246 Mook (1971), demonstrated that river inputs led to a $-8.5 \%$ change in the isotope values which contributed to 247 the $\delta^{18} \mathrm{O}_{\text {water }}$ value of seawater as $-2 \%$ (SMOW). This estimation appears lower than our calculations using the

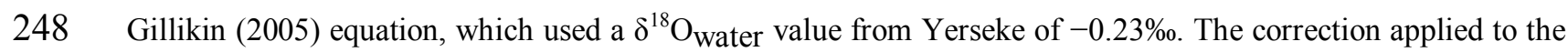
$249 \delta^{18} \mathrm{O}_{\text {water }}$ from Yerseke site led to a lower predicted ST (Figure 7). Even if these new predicted ST's are closer 
to the measured in situ ST's, we cannot exclude the effect of slow winter shell growth rate fluctuations on the 251 measured isotopic signals in the oyster shells. Any reconstruction of the seasonal amplitude of seawater 252 temperatures should take this phenomenon into account.

Another explanations than a large decrease in shell growth rate for oysters from northern areas was given 254 by Elliot et al. (2003). Using theoretical and measured $\delta^{18} \mathrm{O}_{\mathrm{w}}$ with latitude over the northern American continent, 255 they show potential seasonal variability of the $\delta^{18} \mathrm{O}_{\mathrm{w}}$-salinity relationship. In their study, the low values of $\delta^{18} \mathrm{O}_{\mathrm{w}}$, 256 corresponding to local river water inputs, where not monitored by the equation calibrated for most saline waters. 257 However, strong difference between measured and predicted $\delta^{18} \mathrm{O}_{\mathrm{w}}$ appeared for salinities below 5 PSU in Elliot 258 et al. (2003). No fall as much was observed in Dutch and French coastal waters but seasonal variations in the $259 \delta^{18} \mathrm{O}_{\mathrm{w}}$-salinity used in our works can be a field of investigation.

Summary

Cathodluminescence of polished radial sections of oyster Crassostrea gigas hinges demonstrated seasonal 264 patterns of luminescence that were used to determine the oysters age and to establish a chronological scale along the shell hinges. The seasonal pattern of luminescence was used to define the positions for drilling of samples of shell carbonate for stable isotope analyses.

The $\delta^{18} \mathrm{O}$ of oyster shells sampled from different coastal areas in the Netherlands and France allowed the latitudinal reconstruction of the annual seawater temperature range for specific locations along the French North Atlantic and Dutch North Sea. Hinges of C. gigas shells contain an ontogenetic record of the seawater temperature at which the shell was deposited and were reliably used to reconstruct the seasonal amplitude of seawater temperatures in oysters from locations along the French coastline. However, oysters from the Dutch

272 North Sea and the north of France could not be used to determine the winter seawater minima because of (1) the 273 slow growth rate of the hinge during winter lead to time averaging of isotopic records due to the mixing of 274 winter and mid-season shell carbonate samples and (2) a potential variability in $\delta^{18} \mathrm{O}_{\mathrm{w}}$-salinity relationship at low 275 salinities. Future reconstructions of the seasonal range of seawater temperatures from C. gigas shell hinges 276 should take this into account.

\section{Acknowledgements}


The authors would like to thank Fabienne Rauflet, Edouard Bédier, Patrick Soletchnik, Philippe Geairon,

281 Danièle Maurer, Florence D'Amico and Marianne Alunno-Bruscia from IFREMER, as well as Joana Cardoso 282 from the NIOZ, for providing the oysters used in this investigation. This work could have been accomplished 283 without the hydrographic data from the IFREMER marine stations from Port-en-Bessin, Fort-Espagnol, La 284 Tremblade and Arcachon. This study was supported financially by the UPMC (Univ. Paris 06) via the Marc de 285 Rafelis BQR project High Frequency to Very High Frequency Recordings of Environmental Changes to Climate 286 by Biomineralizations ».

\section{References}

Anderson TF, Arthur MA (1983) Stable isotopes of oxygen and carbon and their application to sedimentologic and paleoenvironmental problems. In: Arthur MA, Anderson TF, Kaplan IR, Veizer J, Land L (eds) Stable Isotopes in Sedimentary Geology, vol. Society of Economic Paleontologists and Mineralogists, Short Course, Dallas, pp 1-151

Arthur MA, Williams DF, Jones DS (1983) Seasonal temperature-salinity changes and thermocline in the midAtlantic Bight as recorded by the isotopic composition of bivalves. Geology 11:655-659

Barbin V (2000) Cathodoluminescence of carbonate shells: biochemical vs diagenetic process. In: Pagel M, Barbin V, Blanc P, Ohnenstetter D (eds) Cathodoluminescence in geosciences, vol. Springer Verlag, Berlin, pp 303-329

Barbin V, Ramseyer K, Debenay JP, Schein E, Roux M, Decrouez D (1991) Cathodoluminescence of Recent biogenic carbonates: an environmental and ontogenic fingerprint. Geol Mag 128(1):19-26

Carriker MR, Palmer RE (1979) A new mineralized layer in the hinge of the oyster. Science 206:691-693

Carter JG (1980) Selected mineralogical data for the Bivalvia. In: Rhoads DC, Lutz RA (eds) Skeletal growth of aquatic organisms, vol. Plenum Press, New York, pp 627-643

Chauvaud L, Lorrain A, Dunbar RB, Paulet Y-M, Thouzeau G, Jean F, Guarini J-M, Mucciarone D (2005) Shell of the Great Scallop Pecten maximus as a high frequency archive of paleoenvironmental change. Geochem Geophys Geosyst 6:1-34

Dettman DL, Flessa KW, Roopnarine PD, Schöne BR, Goodwin DH (2004) The use of oxygen isotope variation in shells of estuarine mollusks as a quantitative record of seasonal and annual Colorado River discharge. Geochim. Cosmochim. Acta 68:1253-1263 
311 Galstoff PS (1964) The American oyster, Crassostrea virginica Gmelin. US Fish Wild Serv Fish Bull 64:67-74

312 Gillikin DP (2005) Geochemistry of Marine Bivalve Shells: the potential for paleoenvironmental reconstruction. PhD Thesis, Vrije Universiteit

314 Gillikin DP, Lorrain A, Bouillon S, Willenz P, Dehairs F (2006) Stable carbon isotopic composition of Mytilus edulis shells: relation to metabolism, salinity, $\delta^{13} \mathrm{C}$ DIC and phytoplancton. Organic Geochemistry 37 : $1371-1382$

Goodwin DH, Schöne BR, Dettman DL (2003) Resolution and fidelity of oxygen isotopes as paleotemperature proxies in bivalve mollusk shells: models and observations. Palaios 18:110-125

Harrington RT (1989) Aspects of growth deceleration in Bivalves: clues to understanding the seasonal $\delta^{18} \mathrm{O}$ and $\delta^{13} \mathrm{C}$ record - A comment on Krantz et al. (1987). Palaeogeogr., Palaeoclimatol., Palaeoecol. 70:399-407

Harwood AJP, Dennis PF, Marca AD, Pilling GM, Milner RS (2008) The oxygen isotope composition of water masses within the North Sea. Estuarine Coastal and Shelf Scie 78: 353-359

Higuera-Ruiz R, Elorza J (2009) Biometric, microstructural, and high-resolution trace element studies in Crassostrea gigas of Cantabria (Bay of Biscay, Spain): Anthropogenic and seasonal influences. Estuarine Coastal Shelf Sci 82:201-213

Hong W, Keppens E, Nielsen P, Van Riet A (1995) Oxygen and carbon isotope study of the Holocene oyster reefs and paleoenvironmental reconstruction on the northwest coast of Bohai Bay, China. Mar. Geol.

Hussenot J, Buchet V (1998) Marais maritimes et aquaculture. Activités durables pour la préservation et

Jones DS, Quitmyer IR (1996) Marking time with bivalve Shells: oxygen isotopes and season of annual increment formation. Palaios 11:340-346

Kennedy H, Richardson CA, Duarte CM, Kennedy DP (2001) Oxygen and carbon isotopic profiles of the fan mussel, Pinna nobilis, and reconstruction of sea surface temperatures in the Mediterranean. Mar Biol $139: 1115-1124$

Khim B-K, Woo KS, Je J-G (2000) Stable isotope profiles of bivalve shells: seasonal temperature variations, latitudinal temperature gradients and biological carbon cycling along the east coast of Korea. Cont. Shelf Res. 20:843-861 
Killingley JS, Berger WH (1979) Stable isotopes in a mollusk shell: detection of upwelling events. Science 205(13):186-188

341 Kirby MX (2001) Differences in growth rate and environment between Tertiary and Quaternary Crassostrea oyster. Paleobiology 27(1):84-103

343 Kirby MX, Soniat TM, Spero HJ (1998) Stable isotope sclerochronology of Pleistocene and Recent oyster shells (Crassostrea virginica). Palaios 13:560-569

Langlet D (2002) Enregistrement haute fréquence des conditions environnementales par les tests de bivalves. Application des techniques de marquage, cathodoluminescence, et chimie à l'huître Crassostrea gigas de l'étang de Thau (Hérault, France). PhD Thesis Univ UPMC-Paris 06

Langlet D, Alunno-Bruscia M, Rafélis M, Renard M, Roux M, Schein E, Buestel D (2006) Experimental and natural manganese-induced cathodoluminescence in the shell of the Japanese oyster Crassostrea gigas (Thunberg, 1793) from Thau Lagoon (Hérault, France): ecological and environmental implications. Mar. Ecol. Prog. Ser. 317:143-156

Lartaud F, Langlet D, de Rafelis M, Emmanuel L, Renard M (2006) Description of seasonal rythmicity in fossil osyter shells Crassostrea aginensis Tournouer, 1914 (Aquitanian) and Ostrea bellovacina Lamarck, 1806 (Thanetian). Cathodoluminescence and sclerochronological approaches. Geobios 39:845-852

Lartaud F (2007) Les fluctuations haute fréquence de l'environnement au cours des temps géologiques. Mise au point d'un modèle de référence actuel sur l'enregistrement des contrastes saisonniers dans l'Atlantique nord. PhD Thesis Univ. UPMC-Paris 06

Lawrence DR (1988) Oysters as geoarcheologic objects. Geoarcheology 3:267-274

Loosanoff VL, Nomejko CA (1949) Growth of oysters, O. virginica, during different months. Biol Bull 97:82-94

Mook WG (1971) Paleotepemratures and chlorinities from stable carbon and oxygen isotopes in shell carbonate. Palaeogeogr., Palaeoclimatol., Palaeoecol. 9:245-263

Mueller-Lupp T, Erlenkeuser H, Bauch HA (2003) Seasonal and interannual variability of Siberian river discharge in the Laptev Sea inferred from stable isotopes in modern bivalves. Boreas 32:292-303

Pirastru L (1994) The Bay of Bourgneuf underground salt water: physicochemical characteristics, bioavailability of phosphates and potential fertility for Skeletonema costatum (Grev.) Cleve. PhD Thesis Univ. Nantes 
Richardson CA, Collis SA, Ekaratne K, Dare P, Key D (1993) The age determination and growth rate of the European flat oyster, Ostrea edulis, in British waters determined from acetate peels of umbo growth lines. ICES J. Mar. Sci. 50:493-500

Richardson CA (2001) Molluscs as archive of environmental change. Oceanography and Marine Biology - An Annual Review 39:103-164

Schein E, Roux M, Barbin V, Chiesi F, Renard M, Rio M (1991) Enregistrement des paramètres écologiques par la coquille des bivalves: approche pluridisciplinaire. Bull. Soc. Geol. Fr. 162:687-698

Schmidt GA (1999) Forward modeling of carbonate proxy data from planktonic foraminifera using oxygen isotope tracers in a global ocean model. Paleoceanography 14:482-498

Schöne BR (2003) A "clam-ring" master-chronology constructed from a short-lived bivalve mollusc from the northern Gulf of California, USA. The Holocene 13:39-49

Schöne BR, Tanabe K, Dettman DL, Sato S (2003) Environmental controls on shell growth rates and $\delta^{18} \mathrm{O}$ of the shallow-marine bivalve mollusk Phacosoma japonicum in Japan. Mar. Biol. 142:473-485

Schöne BR, Freyre Castro AD, Fiebig J, Houk SD, Oschmann W, Kröncke I (2004) Sea surface water temperatures over the period 1884-1983 reconstructed from oxygen isotope ratios of a bivalve mollusk shell (Arctica islandica, southern North Sea). Palaeogeogr., Palaeoclimatol., Palaeoecol. 212:215-232

Stenzel HB (1963) Aragonite and calcite as constituents of adult oyster shells. Science 142:232-233

Stenzel HB (1971) Oysters. In: Moore RC (ed) Treatise in Invertebrate Paleontology, Mollusca 6, Bivalvia., vol. Geological Society of America, University of Kansas, pp 271

Surge D, Lohmann KC, Dettman DL (2001) Controls on isotopic chemistry of the American oyster, Crassostrea virginica: implications for growth patterns. Palaeogeogr., Palaeoclimatol., Palaeoecol. 172:283-296

Tivollier J, Létolle R (1968) Résultat et interprétation d'analyses isotopiques de faunes malacologiques du Tertiaire parisien. Bureau de Recherches Géologiques et Minières, Memoires, Paris, pp 347-358.

Wisshak M, Lopez-Correa M, Gofas S, Salas C, Taviani M, Jakobsen J, Freiwald A (2009) Shell architecture, 
399 Table 1: Summary of the locations where Crassostrea gigas were collected from the Netherlands and France.

400

401 Table 2: Average and range of carbon isotope composition and predicted seawater temperatures determined from 402 oxygen isotope ratios in replicate oyster Crassostrea gigas shell hinges from seven locations in the Netherlands 403 and France.

404

405 Table 3: Comparison of the summer and winter predicted seawater temperatures calculated from the stable 406 isotopic composition of the hinges of oyster, Crassostrea gigas shells and the measured seawater temperature 407 range at seven different locations in the Netherlands and France. Significant difference between the predicted 408 and measured seawater temperatures are shown * $(\mathrm{p}<0.05)$.

409 
413 Figure 1: Map to show the seven locations in the Netherlands and France where the oyster Crassostrea gigas, 414 shells were transplanted and collected. The Netherlands locations (1) Texel and (2) Yerseke and the French 415 locations, (3) Baie des Veys, (4) Fort-Espagnol, (5) Marennes-Oléron, (6) Tès, and (7) Ferret are shown. The 416 inset shows in detail the positions of sites 6 and 7 in Arcachon Bay. Nursery tanks were located at Bouin (Nur). 417 B : Belgium ; D ; Netherlands ; DK : Germany ; F : France ; MO ; Morrocco ; NL ; Netherlands ; P : Portugal ; 418 SP : Spain ; SW : Switzerland ; UK : United Kingdom.

Figure 2: Left shell valve of Crassostrea gigas showing the position of the hinge region and inset the appearance of a polished radial section of the foliated calcite hinge sectioned through its longest axis.

Figure 3: Upper figure composite photomicrograph of the hinge region of the oyster Crassostrea gigas (shell number PBr13, from Baie des Veys to illustrate the seasonal variation in cathodoluminescence along the transect A-A'. Middle figure, more luminescent areas are associated with the summer period of hinge growth whereas during winter deposition of the hinge a low level of luminescence occurs and lower figure allocation of periods of luminescence to calendar dates.

Figure 4: Comparison of the seasonal variation in seawater temperature (black line) and salinity (grey line) from the seven different study locations.

Figure 5: Seasonal changes in $\delta^{18} \mathrm{O}$ (closed circles) and $\delta^{13} \mathrm{C}$ (open circles) in Crassostrea gigas shells grown at 433 the seven study locations. Note that the $\delta^{18} \mathrm{O}$ axis has been inverted. The gray bands correspond to the nursery 434 period at Bouin station. The number of each oyster analysed is in parenthesis. A: Texel (Te 3); B: Yerseke (Ye 435 1); C: Baie des Veys (PBr13); D: Fort-Espagnol (FEs 20); E: Marennes-Oléron (MO 17); F: Tès (TES 2); G: 436 Ferret (FERT 6).

438 Figure 6: Comparison of the in situ measured (grey) and reconstructed (black) seawater temperatures for 439 different Crassostrea gigas shells grown at seven locations along a latitudinal gradient from the Dutch North Sea 440 to the French North-East Atlantic coasts. Each shell number is shown in parentheses. A: Texel (Te 3); B: 
441 Yerseke (Ye 1); C: Baie des Veys (PBr13); D: Fort-Espagnol (FEs 20); E: Marennes-Oléron (MO 17); F: Tès 442 (TES 2); G: Ferret (FERT 6).

443

444 Figure 7: Comparison of the amplitude of the reconstructed seawater temperatures determined from stable 445 isotopes in shell carbonate (black). Winter minimum seawater temperatures (bottom black rectangles), summer 446 maximum (top black rectangles) and annual average temperatures (black circles) recorded in oyster shells along 447 the European North Atlantic and North Sea coasts. The amplitudes of the measured in situ seawater temperatures 448 are shown in grey, and those calculated from isotopic ratios of the shells are in black. Dotted black lines for 449 Dutch sites represent paleotemperature estimation using Mook's (1971) $\delta^{18} \mathrm{O}_{\text {water }}$ measurements. F: France, $450 \quad$ NL: Netherlands. 

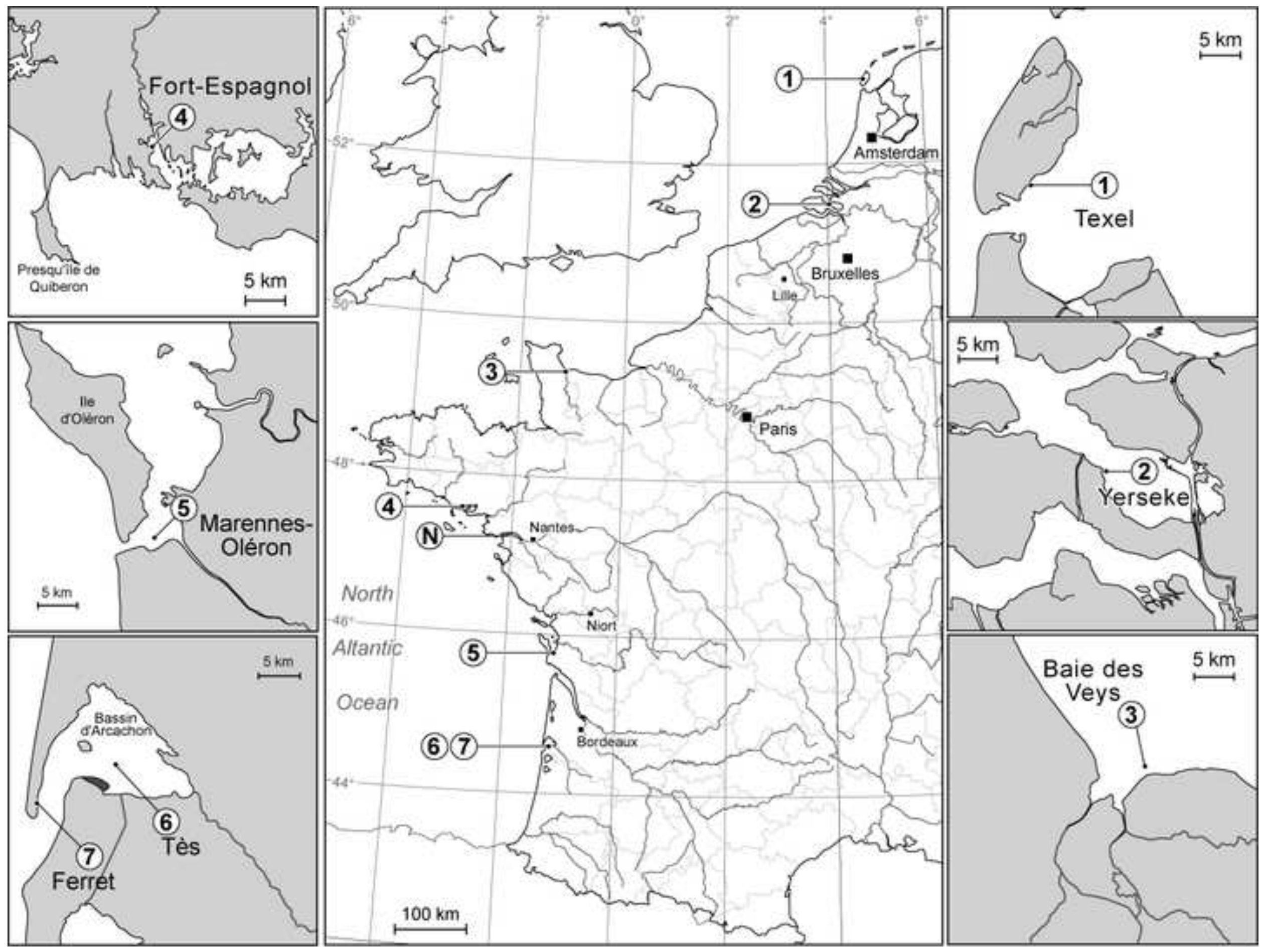
Click here to download high resolution image

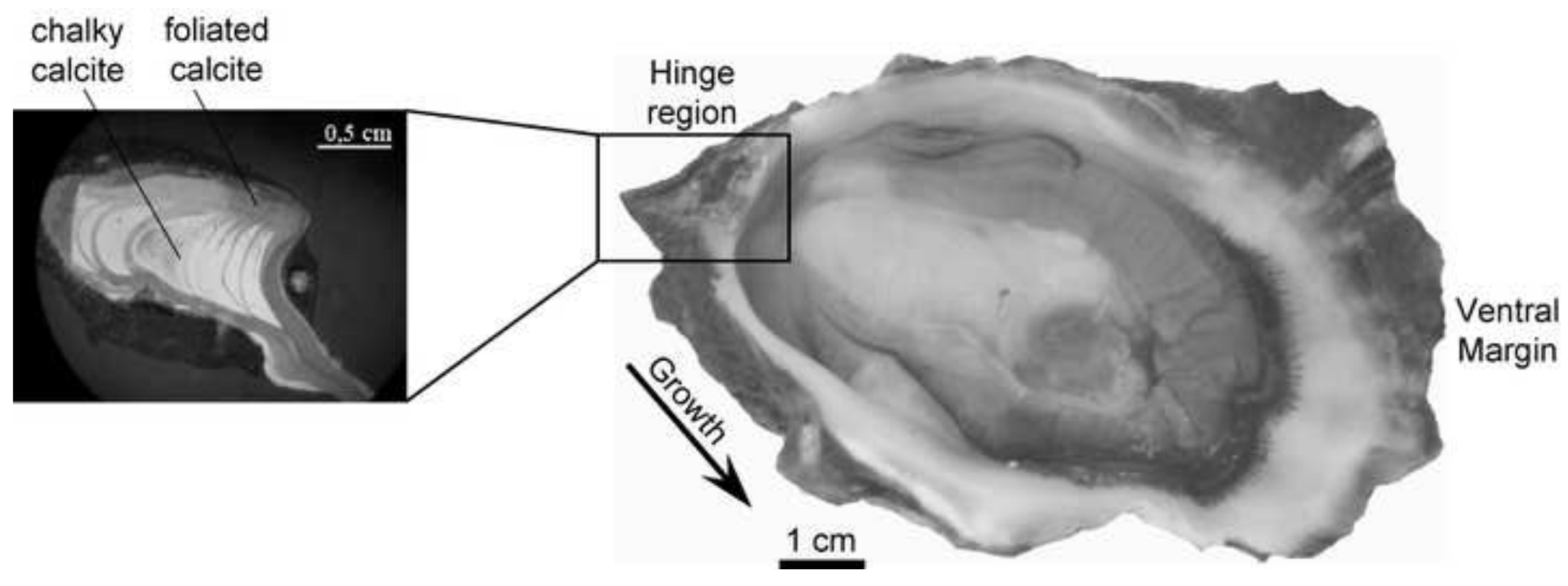




\section{Figure}

Click here to download high resolution image

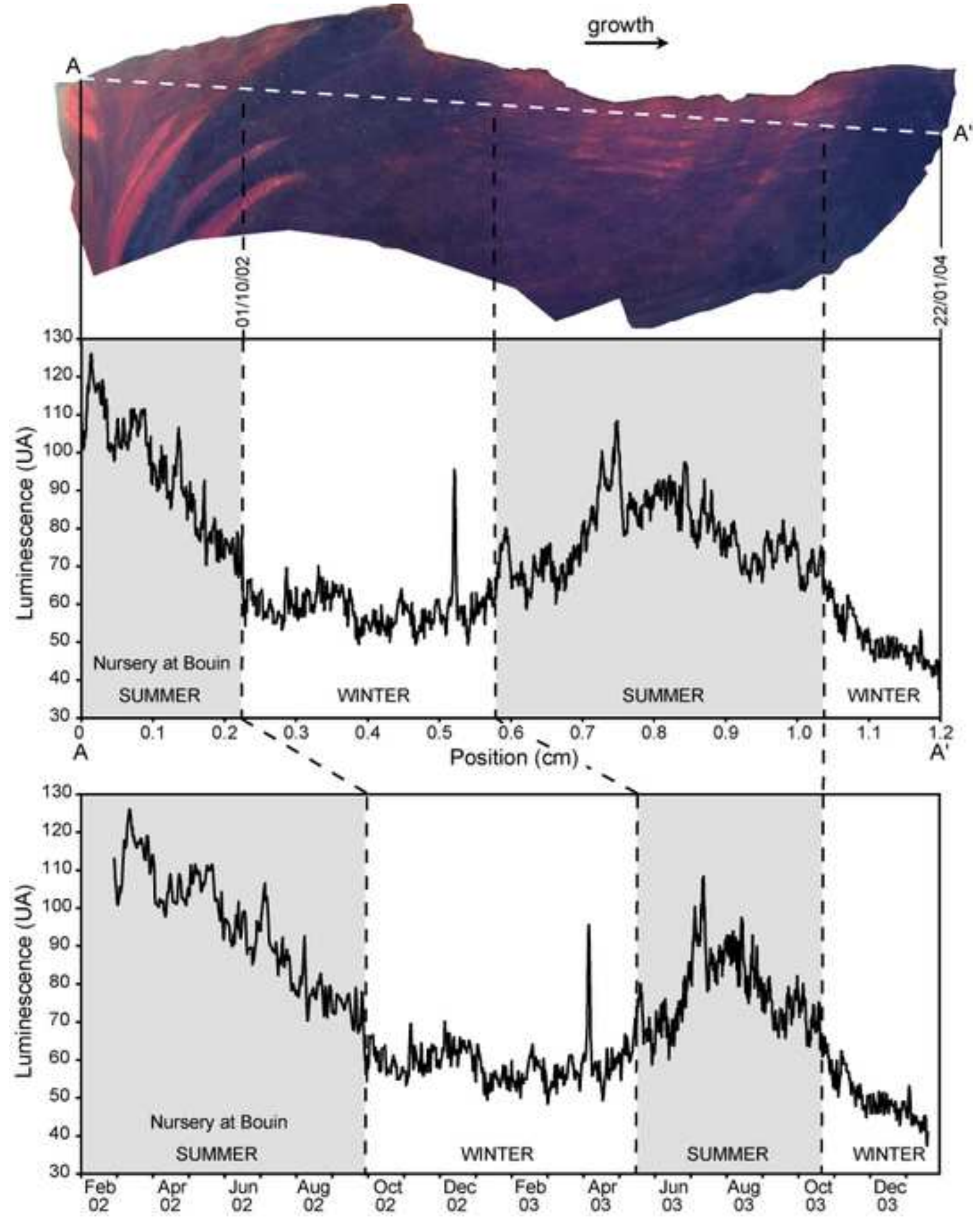



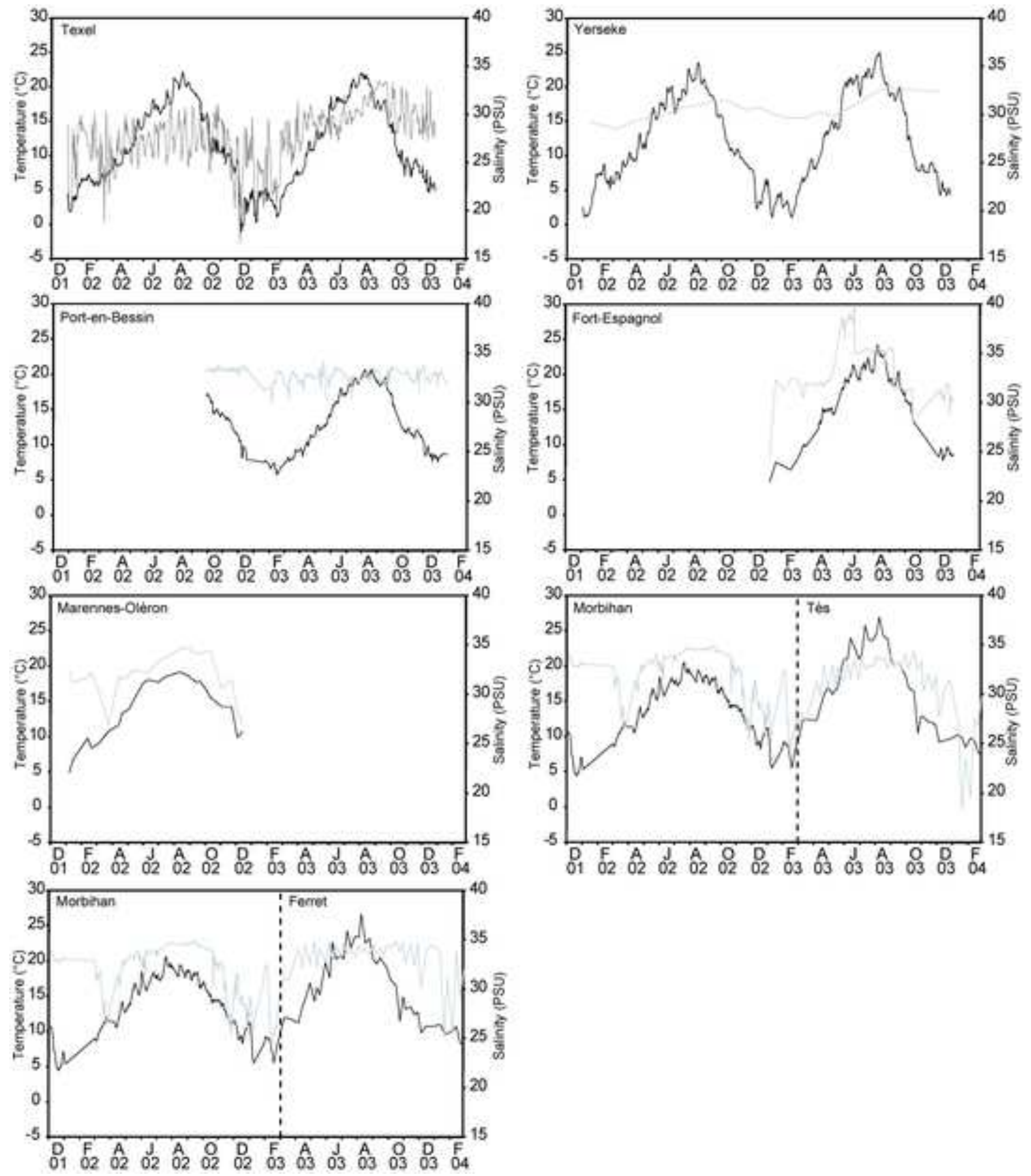

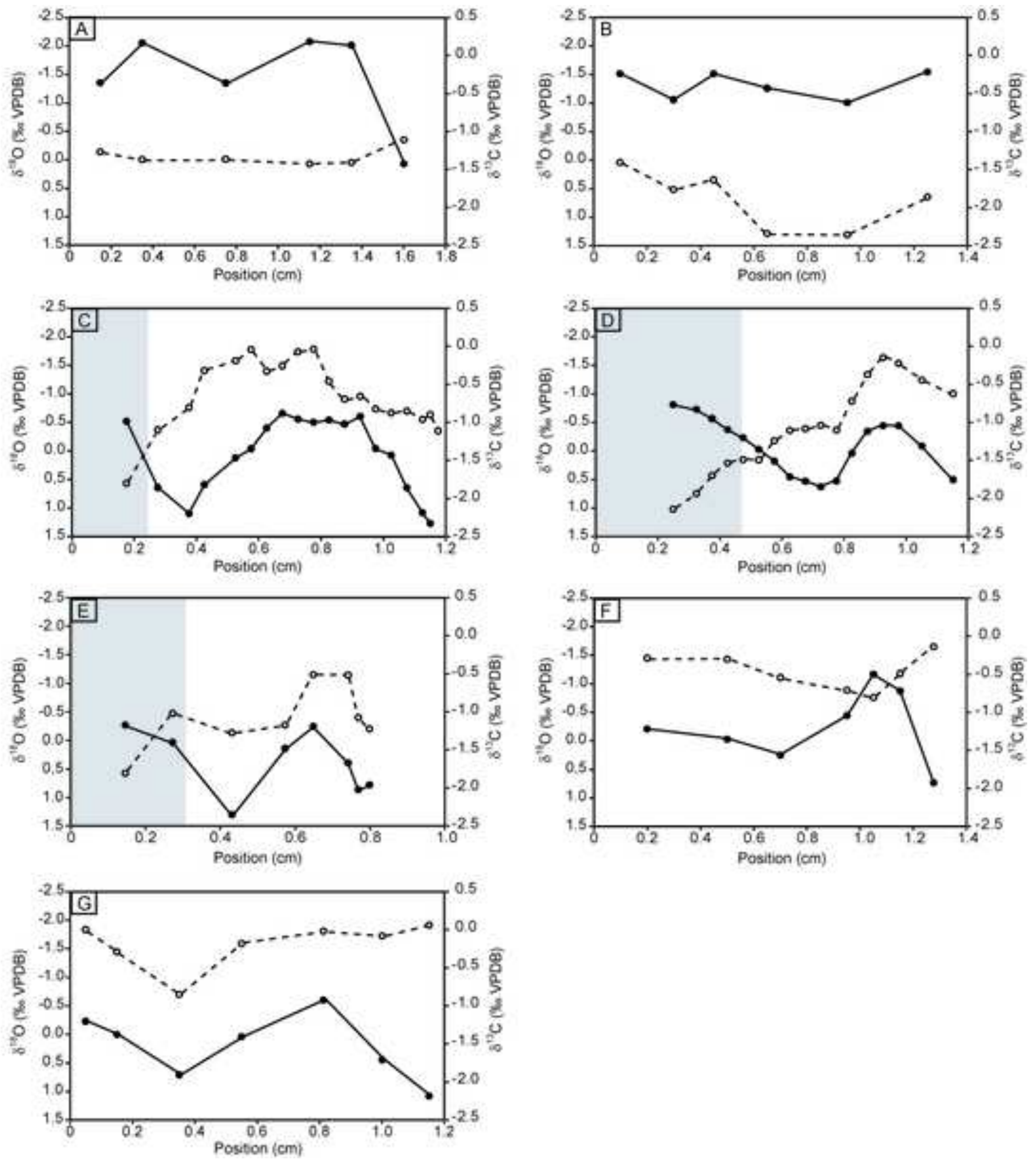


\section{Figure 6}

Click here to download high resolution image
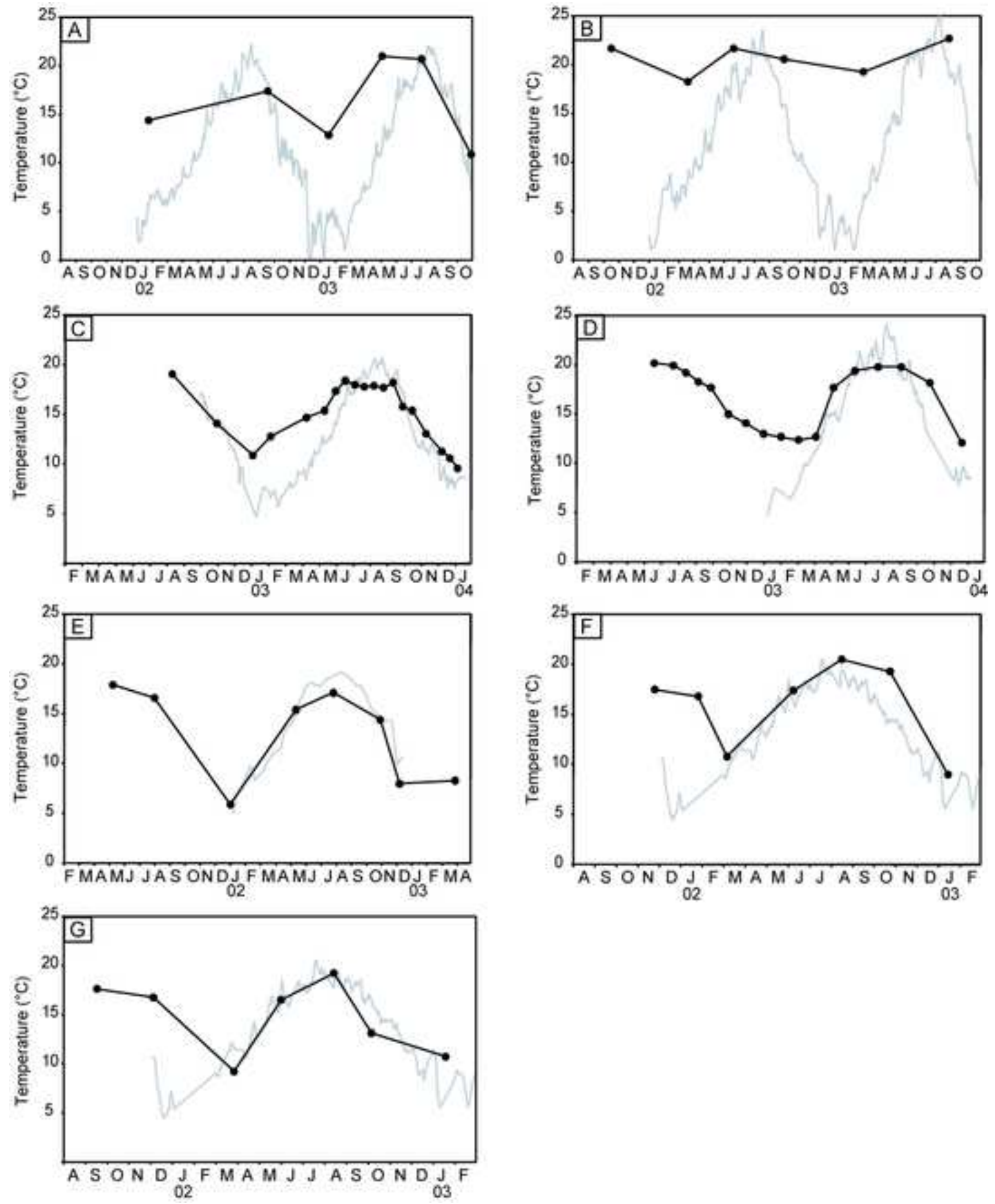
Figure 7

Click here to download high resolution image

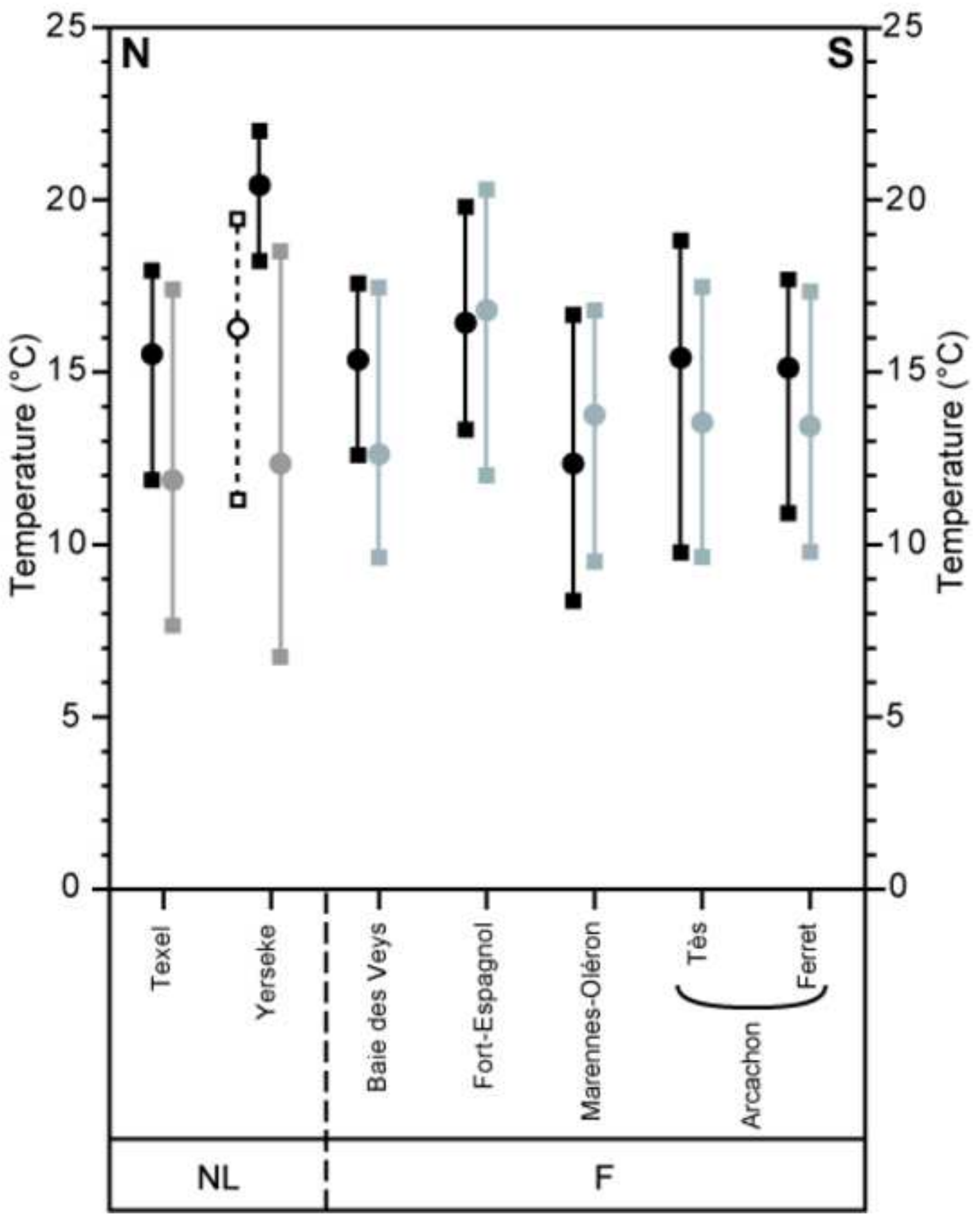


Table 1

\begin{tabular}{|c|c|c|c|c|c|c|}
\hline Location & & $\begin{array}{l}\text { Protected }(P) \text { or } \\
\text { exposed }(E) \\
\text { location }\end{array}$ & $\begin{array}{l}\text { No. of oysters } \\
\text { analysed for stable } \\
\text { oxygen isotopes }\end{array}$ & $\begin{array}{c}\text { Natural }(\mathrm{N}) \text { or } \\
\text { hatchery spat }(\mathrm{H})\end{array}$ & $\begin{array}{c}\text { Date of oyster spat } \\
\text { settlement }\end{array}$ & $\begin{array}{c}\text { Date of collection of } \\
\text { oysters }\end{array}$ \\
\hline \multicolumn{7}{|l|}{ Netherlands } \\
\hline Texel & 1 & $P$ & 2 & $\mathrm{~N}$ & Unknown & October 2003 \\
\hline Yerseke & 2 & $P$ & 2 & $\mathrm{~N}$ & Unknown & October 2003 \\
\hline \multicolumn{7}{|l|}{ France } \\
\hline Baie des Veys & 3 & E & 7 & $\mathrm{H}$ & March 2002 & January 2004 \\
\hline Fort-Espagnol & 4 & $P$ & 6 & $\mathrm{H}$ & March 2002 & January 2004 \\
\hline Marennes-Olèron & 5 & $P$ & 4 & $\mathrm{H}$ & February 2001 & April 2003 \\
\hline Tès & 6 & $\mathrm{P}$ & 2 & $\mathrm{~N}$ & July to August 2001 & March 2004 \\
\hline Ferret & 7 & E & 2 & $\mathrm{~N}$ & July to August 2001 & March 2004 \\
\hline
\end{tabular}




\begin{tabular}{|c|c|c|c|c|c|c|c|c|}
\hline Shell & Locality & $\begin{array}{l}\text { Samples } \\
\text { drilled per } \\
\text { shell }\end{array}$ & $\begin{array}{l}\text { Mean } \\
\delta^{13} \mathrm{C}\end{array}$ & $\min / \max$ & $\begin{array}{l}\text { Mean } \\
\delta^{18} O\end{array}$ & $\min / \max$ & $\begin{array}{c}\text { Mean } \\
\text { predicted } \\
\mathbf{T}^{\circ}\left({ }^{\circ} \mathrm{C}\right)\end{array}$ & $\min / \max$ \\
\hline Te 1 & Texel (the Netherlands) & 4 & -1.45 & $-1.83 /-0.89$ & -1.33 & $-2.48 /-0.69$ & 14.4 & $10.6 / 19.4$ \\
\hline Te 3 & Texel (the Netherlands) & 6 & -1.33 & $-1.43 /-1.11$ & -1.47 & $-2.08 / 0.07$ & 16.2 & $10.9 / 21.0$ \\
\hline Ye 1 & Yerseke (the Netherlands) & 7 & -1.89 & $-2.36 /-1.40$ & -1.32 & $-1.55 /-1.01$ & 20.7 & $18.3 / 22.7$ \\
\hline Ye 2 & Yerseke (the Netherlands) & 4 & -1.81 & $-2.13 /-1.54$ & -1.16 & $-1.71 /-0.17$ & 20.3 & $16.7 / 22.6$ \\
\hline $\mathrm{PBr} 1$ & Baie des Veys (France) & 16 & -1.16 & $-1.57 /-0.76$ & 0.05 & $-0.89 / 1.52$ & 15.4 & $9.6 / 19.4$ \\
\hline $\mathrm{PBr} 12$ & Baie des Veys (France) & 13 & -0.91 & $-1.26 /-0.39$ & 0.29 & $-0.73 / 1.38$ & 14.4 & $10.1 / 18.7$ \\
\hline $\mathrm{PBr} 13$ & Baie des Veys (France) & 17 & -0.64 & $-1.80 /-0.03$ & 0.13 & $-0.66 / 1.52$ & 15.2 & $9.6 / 19.0$ \\
\hline $\mathrm{PBr} 15$ & Baie des Veys (France) & 8 & -1.32 & $-1.73 /-1.02$ & -0.11 & $-1.14 / 0.99$ & 16.0 & $11.3 / 20.5$ \\
\hline PBs 3 & Baie des Veys (France) & 14 & -1.04 & $-1.53 /-0.53$ & 0.04 & $-0.81 / 1.25$ & 15.4 & $10.6 / 19.1$ \\
\hline PBs 16 & Baie des Veys (France) & 14 & -0.58 & $-1.39 / 0.16$ & 0.03 & $-0.83 / 1.11$ & 15.4 & $11.2 / 19.2$ \\
\hline PBs 21 & Baie des Veys (France) & 16 & -1.11 & $-2.04 /-0.76$ & -0.75 & $-0.98 / 1.05$ & 15.7 & $11.0 / 19.8$ \\
\hline FEr 9 & Fort-Espagnol (France) & 7 & -0.66 & $-1.51 /-0.10$ & -0.51 & $-1.24 / 0.14$ & 18.7 & $14.0 / 23.3$ \\
\hline FEr 15 & Fort-Espagnol (France) & 8 & -0.38 & $-1.15 / 0.01$ & -0.01 & $-0.66 / 0.66$ & 16.3 & $12.2 / 20.7$ \\
\hline FEr 21 & Fort-Espagnol (France) & 6 & -0.72 & $-1.21 /-0.45$ & 0.20 & $-0.63 / 0.98$ & 15.5 & $10.2 / 20.6$ \\
\hline FEs 6 & Fort-Espagnol (France) & 10 & -0.52 & $-1.27 /-0.09$ & 0.09 & $-0.65 / 1.17$ & 15.9 & $9.5 / 20.7$ \\
\hline FEs 18 & Fort-Espagnol (France) & 8 & -0.87 & $-1.37 /-0.31$ & -0.16 & $-0.84 / 0.34$ & 17.0 & $12.7 / 21.5$ \\
\hline FEs 20 & Fort-Espagnol (France) & 12 & -0.80 & $-1.49 /-0.15$ & 0.12 & $-0.45 / 0.63$ & 15.6 & $12.1 / 20.2$ \\
\hline MO 5 & Marennes-Oléron (France) & 7 & -1.12 & $-1.76 /-0.44$ & 0.03 & $-0.61 / 0.73$ & 13.9 & $7.9 / 18.6$ \\
\hline MO 6 & Marennes-Oléron (France) & 5 & -1.20 & $-2.32 /-0.31$ & 0.12 & $-0.37 / 0.76$ & 12.4 & $7.8 / 17.5$ \\
\hline MO 9 & Marennes-Oléron (France) & 5 & -1.38 & $-2.28 /-0.68$ & 0.16 & $-0.24 / 0.65$ & 11.1 & $8.2 / 17.0$ \\
\hline MO 17 & Marennes-Oléron (France) & 6 & -0.96 & $-1.27 /-0.51$ & 0.54 & $-0.25 / 1.30$ & 11.5 & $5.9 / 17.1$ \\
\hline TES 1 & Tès - Arcachon (France) & 6 & -0.55 & $-0.71 /-0.34$ & -0.22 & $-1.46 / 0.79$ & 14.7 & $8.7 / 21.8$ \\
\hline TES 2 & Tès - Arcachon (France) & 7 & -0.46 & $-0.80 /-0.13$ & -0.25 & $-1.17 / 0.73$ & 15.9 & $9.0 / 20.5$ \\
\hline FERT 5 & Ferret - Arcachon (France) & 6 & -0.28 & $-0.58 / 0.00$ & 0.05 & $-0.80 / 0.95$ & 15.4 & $10.3 / 20.1$ \\
\hline FERT 6 & Ferret - Arcachon (France) & 7 & -0.19 & $-0.85 / 0.06$ & 0.21 & $-0.60 / 1.08$ & 14.7 & $9.2 / 19.2$ \\
\hline PBr1 & Bouin nursery (France) & 2 & -1.96 & & -0.75 & & 20.0 & \\
\hline $\mathrm{PBr} 12$ & Bouin nursery (France) & 1 & -1.10 & & 0.34 & & 15.3 & \\
\hline $\mathrm{PBr} 13$ & Bouin nursery (France) & 2 & -1.45 & & 0.06 & & 16.6 & \\
\hline $\mathrm{PBr} 15$ & Bouin nursery (France) & 1 & -2.20 & & -0.26 & & 17.8 & \\
\hline PBs 3 & Bouin nursery (France) & 3 & -1.81 & & -0.73 & & 19.9 & \\
\hline PBs 16 & Bouin nursery (France) & 2 & -1.64 & & -0.18 & & 17.5 & \\
\hline PBs 21 & Bouin nursery (France) & 1 & -2.32 & & -0.56 & & 19.1 & \\
\hline FEr 9 & Bouin nursery (France) & 2 & -1.93 & & -0.43 & & 18.6 & \\
\hline FEr 15 & Bouin nursery (France) & 1 & -1.54 & & 0.12 & & 16.2 & \\
\hline FEr 21 & Bouin nursery (France) & 3 & -1.97 & & -0.50 & & 18.9 & \\
\hline FEs 6 & Bouin nursery (France) & 1 & -1.93 & & -0.82 & & 20.2 & \\
\hline FEs 18 & Bouin nursery (France) & 1 & -2.05 & & -0.77 & & 20.1 & \\
\hline FEs 20 & Bouin nursery (France) & 5 & -1.76 & & -0.54 & & 19.1 & \\
\hline MO 5 & Bouin nursery (France) & 2 & -2.01 & & -0.42 & & 18.6 & \\
\hline MO 6 & Bouin nursery (France) & 1 & -1.77 & & -0.26 & & 17.9 & \\
\hline MO 9 & Bouin nursery (France) & 1 & -2.24 & & 0.01 & & 16.7 & \\
\hline MO 17 & Bouin nursery (France) & 2 & -1.41 & & -0.12 & & 17.3 & \\
\hline
\end{tabular}




\begin{tabular}{|c|c|c|c|c|c|c|}
\hline Localities & $\begin{array}{l}\text { Number } \\
\text { of shells }\end{array}$ & Season & $\begin{array}{c}\text { Predicted } \\
\text { temperatures }\end{array}$ & $\begin{array}{c}\text { Average sea water } \\
\text { temperatures } \\
\text { (summer: May to Oct) } \\
\text { (winter: Oct to May) }\end{array}$ & $\begin{array}{l}\text { Difference between } \\
\text { predicted - measured } \\
\text { temperatures }\end{array}$ & $\begin{array}{l}\text { Mann- } \\
\text { Whitney } \\
\text { test }\end{array}$ \\
\hline \multirow[t]{2}{*}{ Texel } & 2 & summer & $18.0 \pm 2.9$ & $17.4 \pm 0.3$ & 0.6 & -0.972 \\
\hline & & winter & $11.9 \pm 2.0$ & $6.7 \pm 0.3$ & 5.2 & $-2.577 x$ \\
\hline \multirow[t]{2}{*}{ Yerseke } & 2 & summer & $22.0 \pm 0.8$ & $18.6 \pm 0.3$ & 3.4 & -2.698 \\
\hline & & winter & $18.2 \pm 2.7$ & $6.8 \pm 0.3$ & 11.4 & -2.985 \\
\hline \multirow[t]{2}{*}{ Baie des Veys } & 7 & summer & $17.6 \pm 0.4$ & $17.5 \pm 0.4$ & 0.5 & -0.589 \\
\hline & & winter & $12.6 \pm 0.5$ & $9.6 \pm 0.3$ & 3 & -7.959 \\
\hline \multirow[t]{2}{*}{ Fort-Espagnol } & 6 & summer & $19.8 \pm 0.6$ & $20.3 \pm 0.3$ & 0.5 & 1.842 \\
\hline & & winter & $13.2 \pm 0.5$ & $12.0 \pm 0.7$ & 1.2 & -0.475 \\
\hline \multirow[t]{2}{*}{ Marennes-Oléron } & 4 & summer & $16.7 \pm 1.0$ & $16.8 \pm 1.1$ & 0.1 & 0.507 \\
\hline & & winter & $8.3 \pm 0.8$ & $9.5 \pm 1.7$ & 1.2 & 2.252 \\
\hline \multirow[t]{2}{*}{ Tès } & 2 & summer & $18.8 \pm 1.4$ & $17.4 \pm 0.4$ & 1.4 & -1.721 \\
\hline & & winter & $9.8 \pm 1.1$ & $9.7 \pm 0.3$ & 0.1 & -0.052 \\
\hline \multirow[t]{2}{*}{ Ferret } & 2 & summer & $17.7 \pm 1.2$ & $17.3 \pm 0.3$ & 0.4 & -0.872 \\
\hline & & winter & $10.9 \pm 1.8$ & $9.8 \pm 0.3$ & 1.9 & -0.691 \\
\hline
\end{tabular}

